\title{
Specify IDH Family Mutation
}

National Cancer Institute

\section{Source}

National Cancer Institute. Specify IDH Family Mutation. NCI Thesaurus. Code C160578.

A request to enter the specific IDH family mutations that were identified in the study. 